\title{
MICROSCOPY OF TAMARIND SEEDS
}

\section{NARKHEDE MB ${ }^{* 1}$, TARE HL ${ }^{2}$, CHUMBHALE DS ${ }^{2}$, CHAUDHARI SR ${ }^{3}$, PATIL KD $^{4}$, DAMA GY AND DEORE SR}

1: Dr. Rajendra Gode College of Pharmacy, Malkapur, Buldana, M.S., India

2: Amrutvahini Sheti and Shikshan Vikas Sanstha's Amrutvahini College of Pharmacy, Sangamner, Savitribai Phule Pune University, M.S., India

3: KJ's Educational Institute's Trinity College of Pharmacy, Pune, M.S., India

4: Dr. Shivajirao Kadam College of Pharmacy, Kasbe Digraj, Sangli, M.S., India

5: Shree Gajanan Maharaj Shikshan Prasarak Mandal's Sharadchandra Pawar College of Pharmacy, Dumbarwadi, Otur, Tal. Junnar, Dist. Pune, M.S., India

6: R. C. Patel Institute of Pharmaceutical Education and Research, Shirpur, Dist. Dhule, M.S., India

*Corresponding Author: Narkhede MB: E Mail: harshaltare51@gmail.com Received $28^{\text {th }}$ May 2020; Revised $4^{\text {th }}$ July 2020; Accepted $5^{\text {th }}$ Aug. 2020; Available online $1^{\text {st }}$ April 2021

\section{https://doi.org/10.31032/IJBPAS/2021/10.4.5425}

\section{ABSTRACT}

In this study, we are reporting anatomical features of seeds of Tamarindus indica Linn. The transverse sections of these seeds are differentiated into two layers outermost is sclerotesta and inner one is sarcotesta. There are two cotyledons which comprise outer layer of smaller square shaped epidermal cells. The ground tissue consists of homogenous, circular, highly thick walled parenchyma cells. Hope, these will surely be useful to global researchers in preparation of pharmacopoeial standards.

\section{Keywords: Microscopical Characteristics, Tamarindus indica Linn, Anatomical features} \section{INTRODUCTION}

Tamarindus indica Linn. belonging to tender leaves and flowers are used Caesalpiniaceae subfamily is commonly extensively in culinary and medicinal identified and known as Chincha in preparations. It's a large wide spreading tree Ayurveda system of medicine [1]. Its fruit, 12 to 18 meters high. The trunk with dark 
rough bark has deep cracks; leaves 5 to $12.5 \mathrm{~cm}$ long, leaflets sub sessile, 10 to 20 pairs; flowers in lax few flowered racemes, petals 3, yellowish with pink stripes; pods pendulous, 7.5 to $20 \mathrm{~cm}$ long, slightly curved, sub compressed; seeds smooth, reddish brown, enveloped by tough leathery membrane [2]. The study was designed to study microscopy of the Tamarind Seeds.

\section{MATERIALS AND METHODS}

\section{Plant Material and Authentication}

Tamarindus indica Linn. seeds were collected from Malshej Hills of Pune District of Maharashtra, India. Authentication of collected plant material was carried out at Botanical Survey of India, Western Regional office, Koregaon Park, Pune. Voucher Specimen (BSI/WRC/Tech/2010/409 HLT2) was deposited for future reference [3].

\section{Microscopic Evaluation}

Transverse sections (T.S.) of soaked Tamarindus indica Linn. seeds were taken using microtome. Seeds were soaked in water to revive the material and when ready fixed in FAA (Formaldehyde Alcohol Acetic Acid, 10\%:50\%:5\% + 35\% water) and sectioned using rotary microtome. Sections were stained by using toluidine blue solution $(0.05 \% \mathrm{w} / \mathrm{v})$ and then mounted on slide with Canada balsam brush [4]. T. S. were observed under Photographic Microscopes at
Plant Anatomy Research Center, Tamil Nadu under Normal and Polarized Lights. Transverse Sections of seeds were studied for different microscopic characters.

Photographs of all microscopic characters were captured, printed, labeled and stored for further referencing [5].

\section{RESULTS AND DISCUSSION}

\section{Structure of the Seeds}

The seed coat measures about $390 \mu \mathrm{m}$ thick. It is differentiated into outermost region of sclerotesta and inner sarcotesta. The outer sclerotesta includes two types of cells, the outermost part is made up of narrowly cylindrical compact, palisade like macro sclereids. The cell wall are thick and lignified and cell lumen is very narrow. Inner to the palisade zone is narrow layer of osteosclereids. The cells of osteosclereids are narrow in the middle and dilated at the ends resembling bone or dumbbell. The sarcotesta is homogenous and parenchymatous. The cells are wide, angular, thin walled and compact. Inner to the seed coat is seen the cotyledons. (Figure 1.1 and 1.2).

There are two cotyledons which comprise outer layer of smaller square shaped epidermal cells. The ground tissue consists of homogenous, circular, highly thick walled parenchyma cells. The cells have highly thick walls with numerous simple pits. Within the 
cells are seen dark amorphous cell inclusions. throughout the cells of cotyledons (Figure

Vascular strands are seen ramifying 2.1, 2.2 and 2.3).

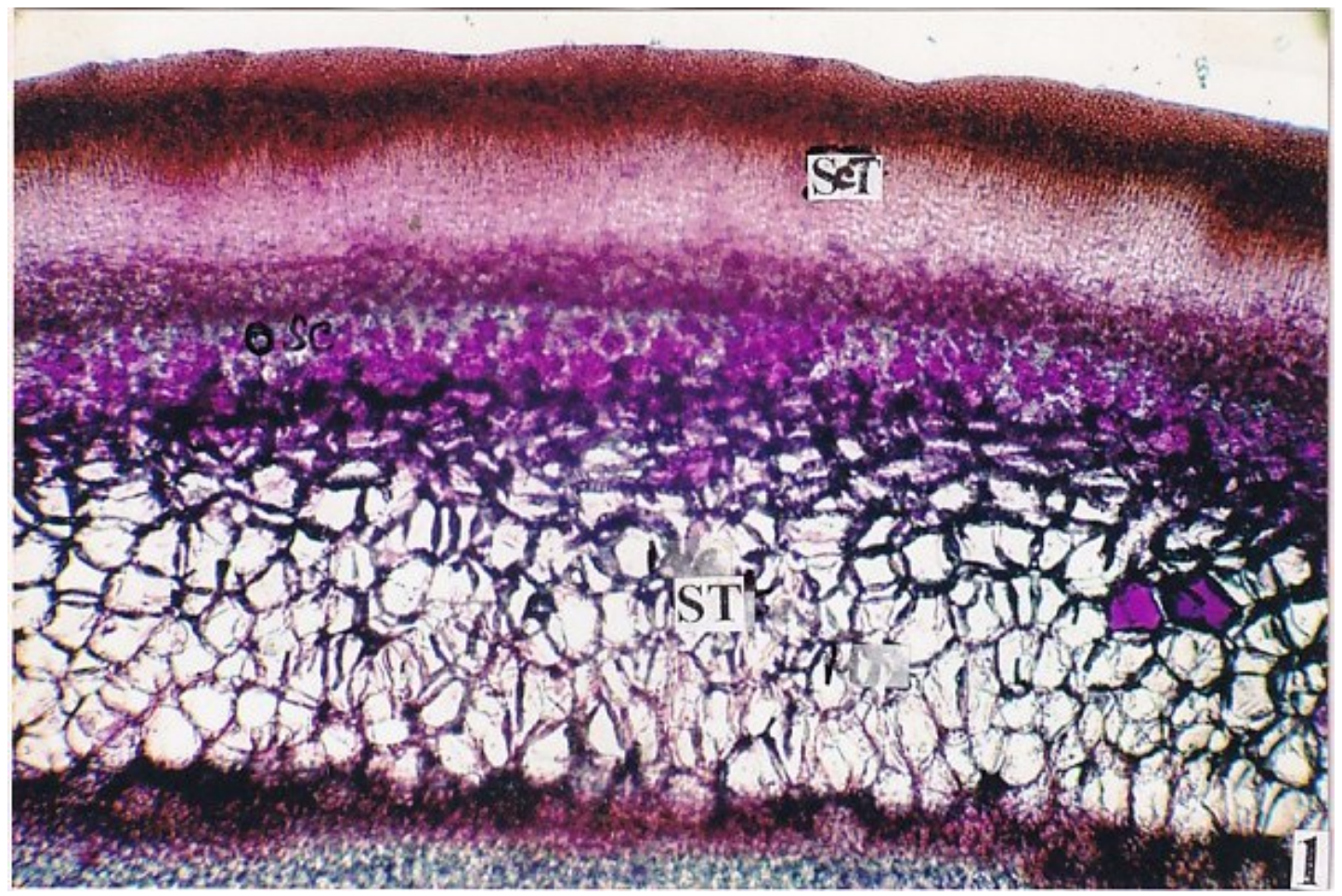

Figure 1.1: T. S. of Seed Coat Stained with Safranin

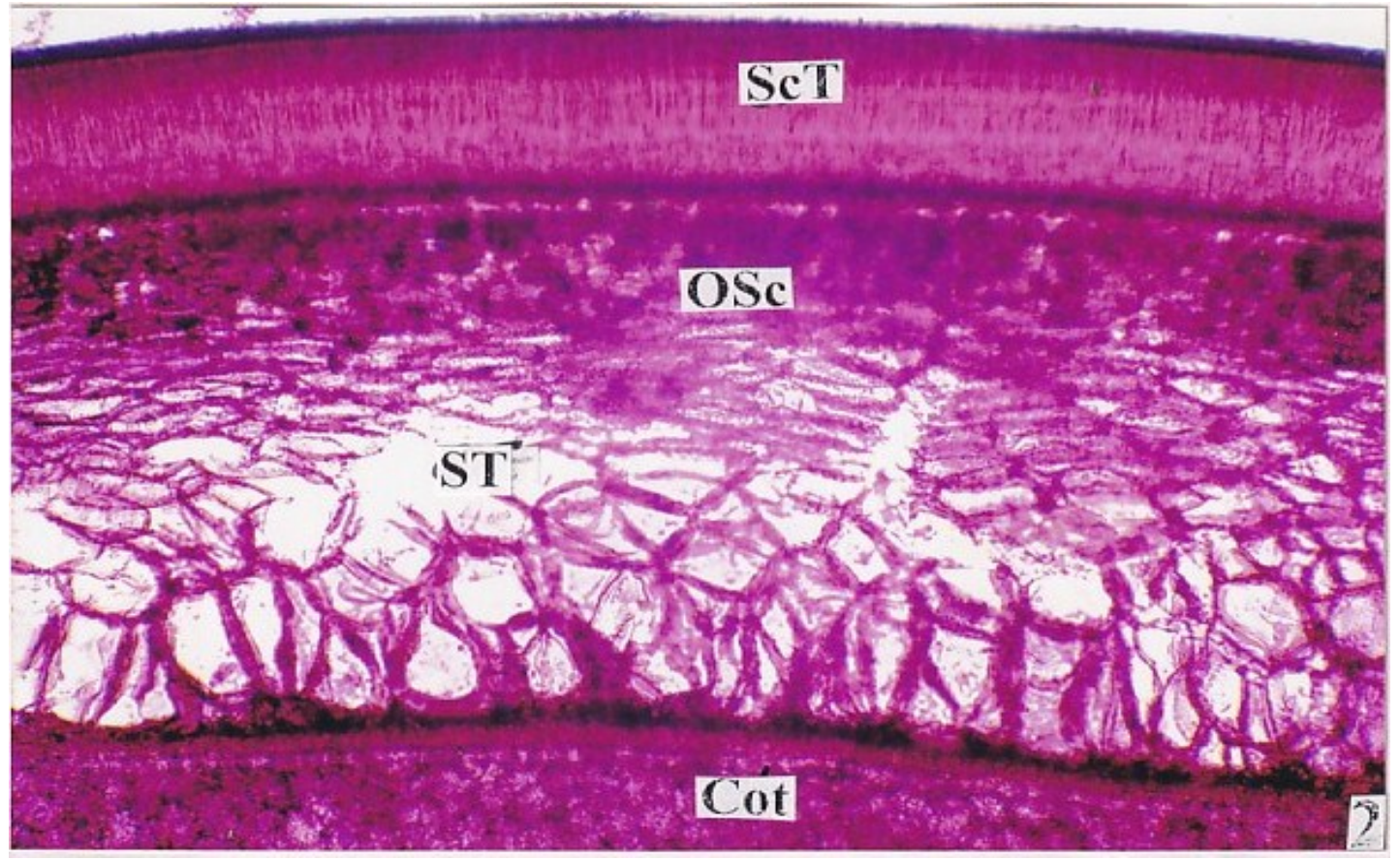

Figure 1.2: T. S. of Seed Coat Stained with Sudan Red

(Cot - Cotyledon, Osc - Osteosclereid, ScT - Sclerotesta, ST - Sarcotesta) 


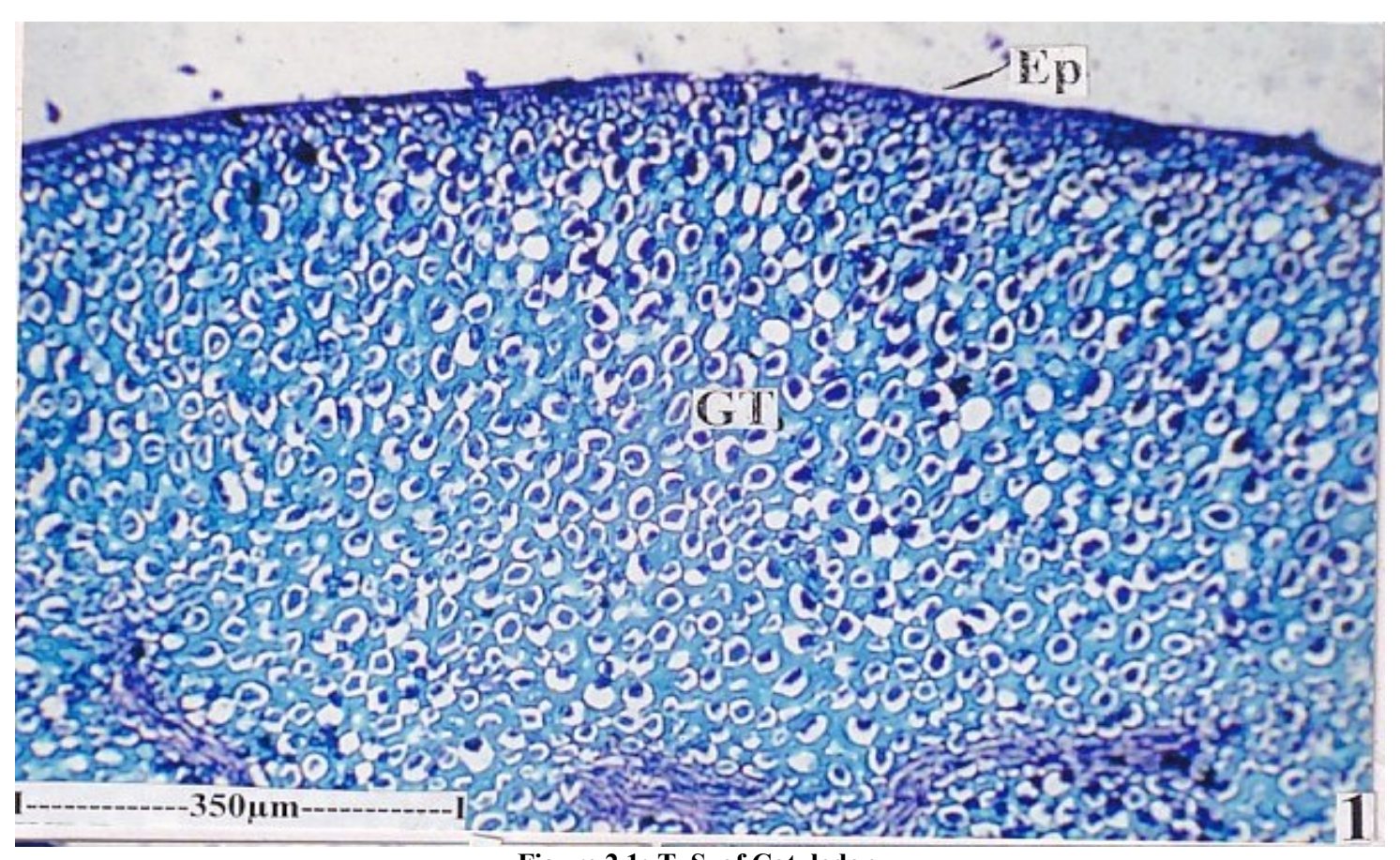

Figure 2.1: T. S. of Cotyledon

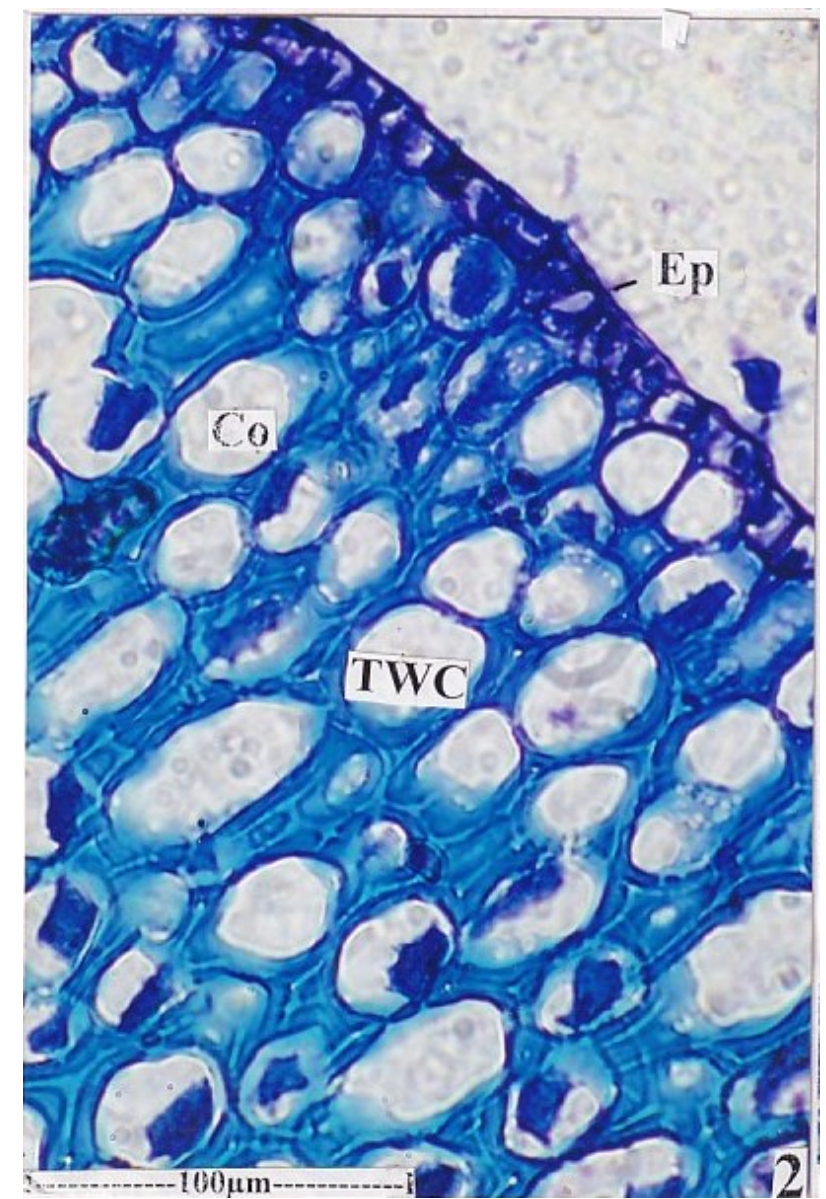

Figure 2.2: T. S. of Cotyledon - A Sector Enlarged 


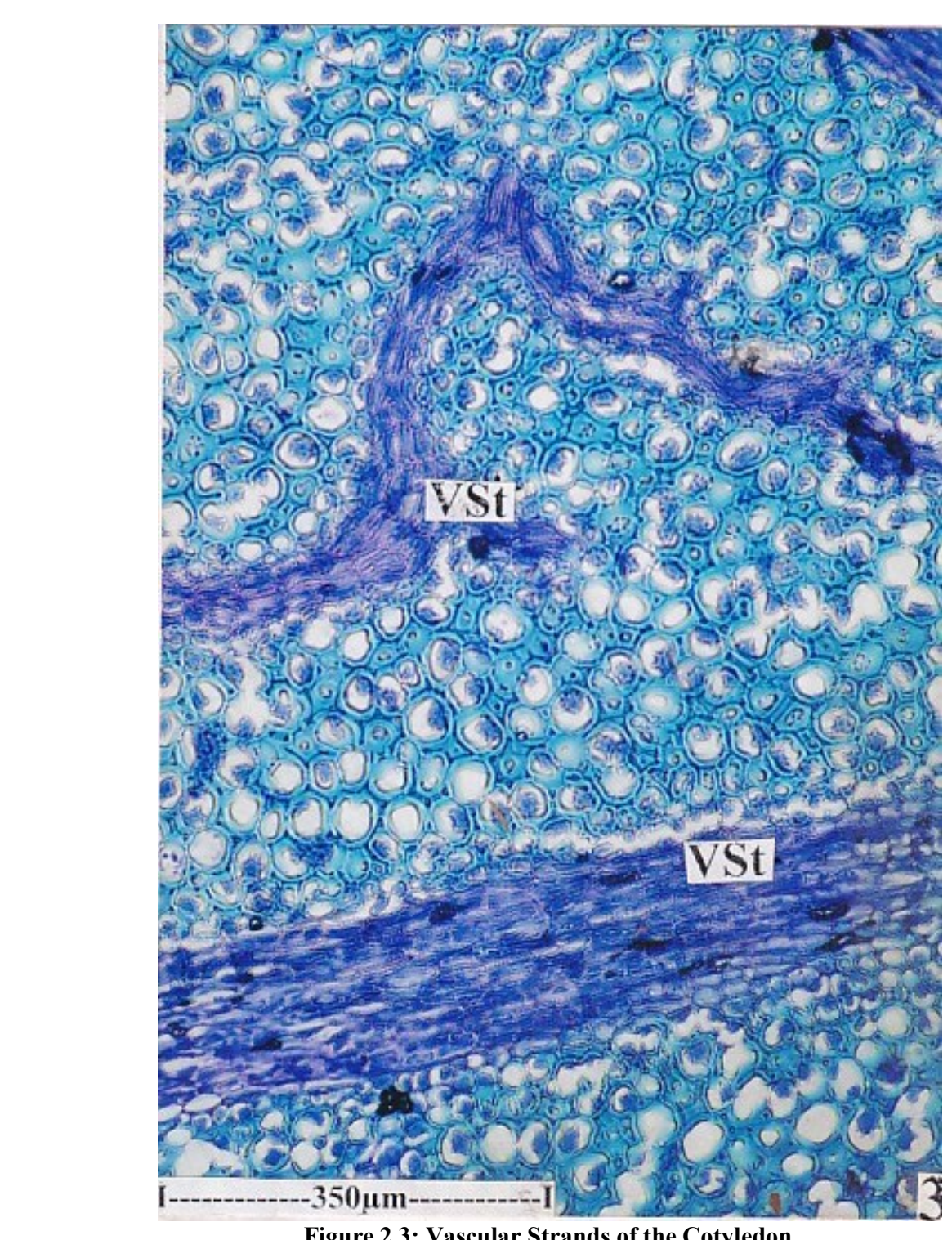

(Co - Cortex, Ep - Epidermis, GT - Ground Tissue, Vst - Vascular Strand, Twc - Thick Walled Cells)

\section{CONCLUSION}

Microscopic characteristics of Tamarindus indica Linn. seeds were successfully determined and reported for the first time. The parameters determined in present study will also be useful for establishing the pharmacopoeia standards for Tamarindus indica Linn.

\section{Source of Funding}

None

\section{Conflict of Interest}

None

\section{ACKNOWLEDGEMENTS}

The authors are thankful to Prof. P. Jayaraman, Director, Plant Anatomy Research Centre, Tambaram, Chennai, 
Tamilnadu, India for the anatomical features and microscopic detailing.

\section{REFERENCES}

[1] Pandey GS, Commentary by KC

Chunekar on Bhavaprakash Nighantu of Acharya Bhavamishra, Amradiphalavarga; $1^{\text {st }}$ Edition, Chapter 6, Verse 142. Varanasi: Chaukambha Bharat Academy, (2013), pp. 586-87.

[2] Kirtikar KR and Basu BD. Indian Medicinal Plants, $2^{\text {nd }}$ Edition, Vol $2^{\text {nd }}$ Dehradun: International Book Distributors; (2006), pp. 887.

[3] Bhadoriya SS, Ganeshpurkar A, Narwaria J, Rai G, Jain AP. Tamarindus indica: Extent of explored potential. Pharmacogn Rev. (2011); 5(9), pp. 7381. doi:10.4103/0973-7847.79102

[4] Raval ND, Pandya TN. Pharmacognostic study of Lepidium sativum Linn (Chandrashura). Ayu. (2011); 32(1), pp. 116-119. doi:10.4103/0974-8520.85742

[5] Rashid S, Zafar M, Ahmad M, et al. Microscopic investigations and pharmacognostic techniques used for the standardization of herbal drug Nigella sativa L. Microsc Res Tech. (2018);81(12), pp. 1443-1450. doi:10.1002/jemt.23110 